\title{
Agronomic performance and physiological quality of pepper seeds under different planting system
}

\author{
Igor Forigo Beloti ${ }^{1}$, Breno Nunes Rodrigues de Azevedo ${ }^{1}$, Gabriel Mascarenhas Maciel ${ }^{1}$, Hugo \\ Gabriel Peres ${ }^{1}$, Mauricio Pivetta Momesso', Igor Matheus Alves ${ }^{1}$ \\ ${ }^{1}$ Universidade Federal de Uberlândia, Campus Monte Carmelo, Monte Carmelo, Minas Gerais, Brasil. E-mail: agroifb@gmail.com, \\ brenoagroufumc@ hotmail.com, maciel.ufu@gmail.com, hugogabrielperes@gmail.com, mauriciomomesso@ hotmail.com, \\ igormatheusalves@hotmail.com
}

Received: 25/03/2019; Accepted: 10/11/2019.

\begin{abstract}
The pepper crop is cultivated in all Brazilian regions, and the planting system with the arrangement of plants in the single-row prevails. Therefore, this work aimed to evaluate the agronomic performance and physiological quality of the seeds of different pepper genotypes according to the planting systems. The experiment was carried out at the Federal University of Uberlândia, in Monte Carmelo, in a randomized blocks experimental design, in a 4 x 2 factorial scheme, four genotypes (UFU-62-5M; UFU-28-1M; UFU-58-6D and UFU-5-3BD) under two planting systems (Single-row planting - SRP and Double-row planting - DRP), with four repetitions. The spacing of $0.6 \mathrm{~m}$ between plants and rows was used in the SRP. In the DRP, the spacing of $0.6 \mathrm{~m}$ between rows and $1.20 \mathrm{~m}$ between plants were used. Each plot was composed of six plants, the two central plants were considered for the evaluations of total production; fruit mass; fruit diameter; fruit length; electric conductivity of seeds; 1000-seeds weight; fruit production; first germination count; and chlorophyll $a$ and $b$. The double-row planting had significant increases in the physiological quality of pepper seeds; thus, for seed production, this would be the best system. Because there are no differences in productivity between the systems, the double-line system would be advantageous to facilitate the harvesting and allow future mechanization.
\end{abstract}

Keywords: Capsicum spp., spacing, cultivation system, seed vigor.

\section{Avaliação de parâmetros agronômicos e da qualidade fisiológica de sementes em pimenteiras cultivadas sob diferentes sistemas de plantio}

\section{RESUMO}

A cultura da pimenteira é cultivada em todas as regiões brasileiras, predominando o cultivo em fileiras simples. Entretanto, desconhece-se se este é o melhor sistema de plantio. Diante disso, este trabalho teve por objetivo avaliar o desempenho agronômico e a qualidade fisiológica de sementes de diferentes genótipos de pimenteira, em resposta ao sistema de plantio. O experimento foi conduzido na Universidade Federal de Uberlândia, Campus de Monte Carmelo, no delineamento experimental de blocos ao acaso, em esquema fatorial $4 \times 2$, sendo quatro genótipos de pimenta (UFU-62-5M; UFU-28-1M; UFU-58-6D e UFU-5-3BD) e dois sistemas de cultivo (Linha Simples - SRP e Linha Dupla - DRP), em quatro repetições. Utilizou-se o espaçamento de 0,6 m entre plantas e entrelinhas para o SRP e 0,6 m entrelinhas e 1,20 m entre plantas, respectivamente, para o DRP. Cada parcela foi composta de seis plantas, sendo consideradas para as avaliações as duas plantas centrais. Avaliaram-se: produção total; peso dos frutos; diâmetro de frutos; comprimento de frutos; condutividade elétrica das sementes; peso de mil sementes; produção por planta; primeira contagem na germinação de sementes; e conteúdo de clorofila $a$ e $b$. O plantio em fileira dupla apresenta incrementos significativos na qualidade fisiológica de sementes de pimenteira, assim, para produção de sementes, este seria o melhor sistema. Devido ao fato de não existir diferenças na produtividade entre os sistemas, o sistema de linha dupla seria vantajoso por facilitar as colheitas e possibilitar futura mecanização das mesmas.

Palavras-chave: Capsicum spp., espaçamento, sistema de cultivo, vigor de sementes. 


\section{Introduction}

The Capsicum sp., commonly known as peppers belongs to the Solanaceae family, are cultivated in tropical and temperate regions, they are valued as spices or vegetables by many different cultures worldwide, also extensively used in food industries. Brazil is the biggest producer of peppers of the Capsicum genus in the world. In the country, this crop had high profitability and social expressiveness, employing a high number of workers (Fonseca et al., 2008; Dutra et al., 2010; FAO, 2016). At present, occupy the second place in the export volume of vegetables in Brazil, behind only the melon (Cucumis melo L.) with a $13.5 \%$ share of the total exported value (Agrianual, 2012).

According to ABCSEM (2009), in 2009, were commercialized around $590 \mathrm{~kg}$ of seeds of stinging and sweet cultivars, with an estimated cultivated area of 1979.89 ha, which shows excellent demand for production and commercialization of quality seeds. However, as the available sources do not have a historical perspective on the vegetable, they are not covered by regional and local market statistics and are not accounted for in the global statistics. Therefore, this demand may be even higher (Domenico et al., 2012).

Despite the economic and social benefits provided by the cultivation of pepper in Brazil, the cultural practices applied in the culture still precarious, given the negligence of researchers, and therefore, there is a lack of scientific studies about the crop. Among the practices that most influence the performance of crops, the choice of the cultivate system, and the responses of different crops are relevant to the effects caused by the different spacings used in the planting, providing significant differences in plant development, weight, and quality of fruits and yield (López-Bellido et al., 2005).

Pôrto et al. (2012) report that the variation in spacing between the rows or between the plants can modify the competition between individuals, with consequences on its growth and development. According to Paulus et al. (2015), planting density does not affect the number of fruits, fruit diameter and length, and soluble solids content in pepper plants. However, they report that the densification can be a strategy to increase the yield of pepper cultivars to the optimization of the use of light, water, nutrients, and weed pressure. Khasmakhi-Sabet et al. (2009) observed that the density of planting in different types of pepper influences growth, development, and commercial production.

In the pepper producing regions of Brazil, the layout of the plants predominates in single rows. However, this arrangement limits harvesting increases plant bumps and losses and is inappropriate for future mechanization, which may lead to lower profitability for producers. Thus, the management of the disposition of plants in an area can be an essential factor to obtain a larger number of fruits with a commercial standard, besides increasing the yield considerably (Goreta et al., 2005).

This work aimed to evaluate differences in the agronomic performance and the physiological quality of the seeds of four pepper genotypes, according to the planting systems.

\section{Material and Methods \\ 2.1. Location}

The experiment was conducted from January to May 2015, at the Experimental Station of Vegetables, the Federal University of Uberlândia, in Monte Carmelo, Minas Gerais, Brazil (18 42' 43,19" S; 47 29' 55.8" W and $873 \mathrm{~m}$ a.s.1.). The climate, according to the classification of Köppen (Köppen and Geiger, 1928), is temperate humid, with hot summers and dry winters.

\subsection{Experimental Design}

The experimental design used was randomized blocks with four replications. The plots were arranged in a $4 \times 2$ factorial scheme, four genotypes belonging to the Capsicum sp. genus [UFU-62-5M and UFU-28-1M (C. frutescens L.); UFU-58-6D (C. baccatum L.) and UFU-5-3BD (C. chinense L.)] in two planting systems (Single-row planting - SRP and Double-row planting DRP).

In the SRP system, Ribeiro and Reifschneider (2008) recommended spacing $0.6 \mathrm{~m}$ between rows and between plants. In the DRP, double rows were used, spacing $0.6 \mathrm{~m}$ between plants and $1.20 \mathrm{~m}$ between rows, by doubling the spacing used in the single-row system. The total area required for the experiment was approximately $138 \mathrm{~m}^{2}$, comprising 32 plots of $4.32 \mathrm{~m}^{2}$, containing six plants per plot, totaling 192 plants. In both systems of planting, the two central plants were considered for evaluations. The density of plants in both systems was 27,778 plants ha ${ }^{-1}$.

The evaluated genotypes come from the Capsicum germplasm bank, located in the Laboratory of Seed Analysis and Genetic Resources (LAGEN) at the Federal University of Uberlândia - UFU, in Monte Carmelo.

\subsection{Management Practices}

For the formation of the seedlings, an indirect sowing system was used in expanded polystyrene trays, with capacity for 200 cells, filled with a commercial substrate based on coconut fiber. The trays were kept in a greenhouse, receiving irrigation by micro-sprinkler from three to four times by day. After reaching from four to five definitive leaves, the seedlings were transplanted to the previously prepared field, with corrected $\mathrm{pH}$ and fertilized. 
The soil was sampled in the $0-0.20 \mathrm{~m}$ layer, and the results of chemical and physical analysis showed the following results: $50 \mathrm{~g} \mathrm{~kg}^{-1}$ of clay; $\mathrm{pH}$ in $\mathrm{CaCl}_{2}=4.9$; organic matter $=3.9 \mathrm{dag} \mathrm{kg}^{-1} ; \mathrm{P}($ Mehlich-1) $=79.1 \mathrm{mg}$ $\mathrm{dm}^{-3} ; \mathrm{K}=0.29 \mathrm{cmol}_{\mathrm{c}} \mathrm{dm}^{-3} ; \mathrm{Ca}=3.3 \mathrm{cmol}_{\mathrm{c}} \mathrm{dm}^{-3} ; \mathrm{Mg}=$ $1.3 \mathrm{cmol}_{\mathrm{c}} \mathrm{dm}^{-3} ; \mathrm{H}+\mathrm{Al}=4.9 \mathrm{cmol}_{\mathrm{c}} \mathrm{dm}^{-3}$; Sum of base $=$ $4.90 \mathrm{cmol}_{\mathrm{c}} \mathrm{dm}^{-3}$; cation exchange capacity $=9.80 \mathrm{cmol}_{c}$ $\mathrm{dm}^{-3}$; soil base saturation $=50 \%$.

After the soil analysis, the calculations of planting and top-dressing fertilization were performed, as well as liming, as required by the pepper crop and according to the recommendations of Ribeiro and Reifschneider (2008). For the control of pests and diseases, insecticides and fungicides were recommended for the crop, according to the occurrence of the etiological agent, insect or pathogen, in the experimental area, and the rate recommended by the manufacturer was adopted. For weed control, manual weeding was performed. Sprinkler irrigation was used, with daily shifts to keep the soil always moist and suitable for the maximum development of the crop, based on daily observations.

\subsection{Data Collection and Analysis}

At fruit maturity at 100 days after transplanting, the agronomic characteristics were evaluated: Total production $(\mathrm{g})$ : obtained through the sum of the values collected during 16 harvests, one per week; The fruit harvested was at the optimum point of maturation, i.e., change of color and firmness of the fruits; Production (g. plant $\left.{ }^{-1}\right)$; The weight of fruits $(\mathrm{g})$ : obtained by dividing the amount harvested per plot by the number of plants of the plot; Fruit diameter (mm): an average of 10 fruits harvested at random; Fruit length (mm): an average of 10 fruits harvested at random; electrical conductivity of seeds $\left(\mu \mathrm{S} . \mathrm{cm}^{-1} \cdot \mathrm{g}^{-1}\right)$ and first germination count (\%).

For the electrical conductivity of seeds $\left(\mu \mathrm{S} . \mathrm{cm}^{-1} \cdot \mathrm{g}^{-1}\right)$ : the mass method (AOSA, 1983) was used, using four samples of 50 seeds per treatment, which were weighed and subsequently immersed in $50 \mathrm{ml}$ of distilled water, with electrical conductivity between 1 and $3 \mu \mathrm{S} . \mathrm{cm}^{-1}$, remaining in the BOD incubator at $25{ }^{\circ} \mathrm{C}$ for 24 hours. After this period, the electric conductivity measurements were obtained using the benchtop conductivity meter model HMCDB-150, in which it expresses the results in $\mu \mathrm{S} . \mathrm{cm}^{-1} . \mathrm{g}^{-1}$ of seed; The 1000 seeds weight $(\mathrm{g})$ : seeds collected at random, drying in the shade for 24 hours.

For the first count (the percentage of normal seedlings), from the sowing period to the seventh day, in the laboratory. Four replicates were used, with 100 seeds each, distributed evenly on germitest paper moistened with distilled water equivalent to 2.5 times the weight of the substrate, arranged in transparent plastic boxes (gerbox), being kept in germinator type
BOD at $25{ }^{\circ} \mathrm{C}$ and a 12-hour controlled photoperiod (Vieira and Krzyzanowski, 1999); Chlorophyll content performed 70 days after sowing with portable CLOROFILOG CFL1030 chlorophyll meter FALKER $^{\odot}$.

The results were submitted to the normality and homogeneity of the variances tests, with no need for data transformation. Then data were submitted to analysis of variance (test F). The analysis of variance was performed using the SISVAR statistical application for each of the evaluated characters (Ferreira, 2011). The averages were compared by the Tukey's test ( $\mathrm{P}$ $\leq 0.05)$.

\section{Results and Discussion}

The conditions of maximum and minimum temperature, precipitation, and relative humidity during the experiment can be visualized in Figures 1 and 2. The accumulated precipitation in the period was $998.6 \mathrm{~mm}$, the average temperature was $22{ }^{\circ} \mathrm{C}$, and the average relative humidity was $73 \%$. These conditions were suitable for the development of the crop following the recommendations of Ribeiro and Reifschneider (2008).

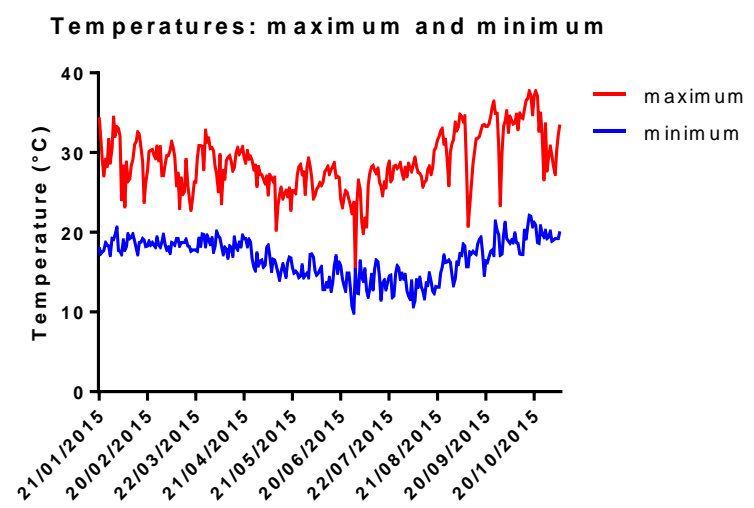

Figure 1. The maximum and minimum temperatures during the experiment, at the Experimental Station of Vegetables, Federal University of Uberlândia, Monte Carmelo-MG, 2015.

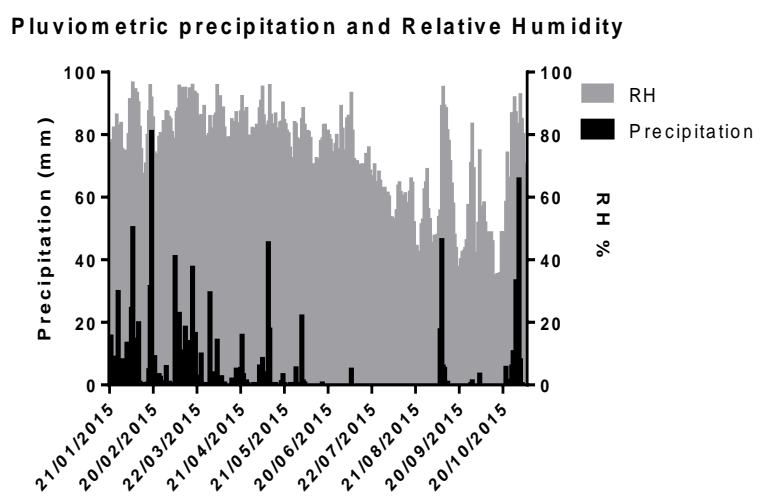

Figure 2. Precipitation and relative humidity, during the experiment, at the Experimental Station of Vegetables, Federal University of Uberlândia, Monte Carmelo, MG, Brazil. 2015. 
No significant difference between the evaluated genotypes nor between the planting systems used for the productivity characteristic was observed (Table 1).

Aminifard et al. (2012) used to study the cultivation of peppers at different planting spacings $(0.20 \mathrm{~m} \times 0.50$ $\mathrm{m}, 0.30 \mathrm{~m} \times 0.50 \mathrm{~m}, 0.20 \mathrm{~m} \times 1.00 \mathrm{~m}$ and $0.30 \mathrm{~m} \times 1.00$ $\mathrm{m})$, which could verify that the total number of fruits is affected by the density of plants, that is, by increasing the number of plants per area, there is a greater number of fruits, while in larger spacings, there is production of less amount of fruit. Likewise, Paulus et al. (2015) state that low planting densities per unit area produce more vigorous plants than at higher population densities, but this does not compensate for the reduction in the number of plants per unit area due to lower production.

In a study by Carvalho et al. (2009) with the BRS Mari (Capsicum baccatum var. Pendulum), produced in the Midwest region of Brazil, obtained high production using the spacing $1.00 \times 1.50 \mathrm{~m}$. This may have occurred because the spacings used in the current experiment in both cultivation systems were lower than the spacing used in the work of Carvalho et al. (2009), which may have provided lower irradiance, greater competition for development factors and, consequently, lower average productivity.
About fruit weight (Table 2), it was observed that there were no significant differences concerning the planting system adopted. Within the SRP, no genotype differed from each other. However, for the DRP, the UFU-58-6 genotype presented a lower result than the others. This genotype also had inferior results for the diameter and length of fruits.

For the 1000-seed weight (Table 3), the genotype UFU-58-6 obtained higher values when cultivated in double-row than when cultivated in a single-row. For the other genotypes, the cultivation system did not influence the seed weight.

The results obtained in this study indicate that the seed weight increases with the highest 1000 -seed weight when the fruits were intensely red. Thus, as the seeds mature physiologically, they accumulate dry matter, and consequently, the seed weight increases (Pereira et al., 2014; Vidigal et al., 2011).

For the electric conductivity of seeds, the genotype UFU-58-6 cultivated in double-row was highlighted concerning to the single-row, which corroborates with Al-Ramamneh (2009), evaluating peas, which affirm that the highest density of plants can restrict light penetration, accumulation of dry matter, thus reducing the development of plants and seed quality.

Table 1. Total production $(\mathrm{g})$ and production per plant $(\mathrm{g})$ for four pepper genotypes in two planting systems. Federal University of Uberlândia, Monte Carmelo-MG, 2015.

\begin{tabular}{lcccc}
\hline \multirow{2}{*}{ Genotypes } & \multicolumn{2}{c}{ Total production $(\mathbf{g})$} & \multicolumn{2}{c}{ Production $\left(\mathbf{g}\right.$. plant $\left.{ }^{-1}\right)$} \\
& Single-row & Double-row & Single-row & Double-row \\
\hline UFU-62-5 & $283.75^{\mathrm{ns}}$ & $252.50^{\mathrm{ns}}$ & $48.79^{\mathrm{ns}}$ & $46.42^{\mathrm{ns}}$ \\
UFU-28-1 & 753.75 & 820.00 & 125.63 & 136.67 \\
UFU-58-6 & 963.75 & 465.00 & 166.29 & 82.58 \\
UFU-5-3 & 581.38 & 457.50 & 93.00 & 86.17 \\
\hline
\end{tabular}

ns: not significant. *Averages followed by uppercase letters in the columns and lowercase letters in the rows differ statistically from each other by the Tukey test at 0.05 of significance.

Table 2. Fruit weight (g), Fruit diameter (mm), Fruit length $(\mathrm{mm})$ for four pepper genotypes in two planting systems. Federal University of Uberlândia, Monte Carmelo-MG, 2015.

\begin{tabular}{lcccccc}
\hline \multirow{2}{*}{ Genotypes } & \multicolumn{2}{c}{ Fruit weights $(\mathbf{g})$} & \multicolumn{2}{c}{ Fruit diameter $(\mathbf{m m})$} & \multicolumn{2}{c}{ Fruit length (mm) } \\
& Single-row & Double-row & Single-row & Double-row & Single-row & Double-row \\
\hline UFU-62-5 & $1.62^{\text {ns }}$ & $2.79 \mathrm{~A}^{*}$ & $12.60 \mathrm{Bb}$ & $17.46 \mathrm{Aa}$ & $30.18 \mathrm{Ba}$ & $31.82 \mathrm{Aa}$ \\
UFU-28-1 & 2.46 & $2.42 \mathrm{~A}$ & $11.36 \mathrm{BCa}$ & $6.33 \mathrm{Bb}$ & $50.73 \mathrm{Aa}$ & $42.27 \mathrm{Aa}$ \\
UFU-58-6 & 0.74 & $0.56 \mathrm{~B}$ & $6.77 \mathrm{Ca}$ & $9.35 \mathrm{Ba}$ & $7.92 \mathrm{Ca}$ & $12.78 \mathrm{Ba}$ \\
UFU-5-3 & 2.25 & $2.32 \mathrm{~A}$ & $18.17 \mathrm{Aa}$ & $17.41 \mathrm{Aa}$ & $15.73 \mathrm{Ca}$ & $18.84 \mathrm{Ba}$ \\
\hline
\end{tabular}

ns: not significant. *Averages followed by uppercase letters in the columns and lowercase letters in the rows differ statistically from each other by the Tukey test at 0.05 of significance

Table 3. Electric conductivity of seeds $\left(\mu \mathrm{S} . \mathrm{cm}^{-1} \cdot \mathrm{g}^{-1}\right)$ and 1000-seed weight $(\mathrm{g})$ for four pepper genotypes in two planting systems. Federal University of Uberlândia, Monte Carmelo-MG, 2015.

\begin{tabular}{lcccc}
\hline Genotypes & \multicolumn{2}{c}{ Electric conductivity } & \multicolumn{2}{c}{ 1000-seed weight } \\
& Single-row & Double-row & Single-row & Double-row \\
\hline UFU-62-5 & $229.03 \mathrm{Ba}$ & $248.32 \mathrm{Ba}$ & $4809.71 \mathrm{Ba}$ & $5214.67 \mathrm{Ba}$ \\
UFU-28-1 & $145.45 \mathrm{Aa}$ & $157.30 \mathrm{Aa}$ & $3054.45 \mathrm{Ca}$ & $3303.18 \mathrm{Ca}$ \\
UFU-58-6 & $205.78 \mathrm{Ba}$ & $273.088 \mathrm{Bb}$ & $4321.33 \mathrm{Bb}$ & $5734.80 \mathrm{Ba}$ \\
UFU-5-3 & $299.83 \mathrm{Ca}$ & $321.90 \mathrm{Ca}$ & $6296.43 \mathrm{Aa}$ & $6759.81 \mathrm{Aa}$ \\
\hline
\end{tabular}

ns: not significant. *Averages followed by uppercase letters in the columns and lowercase letters in the rows differ statistically from each other by the Tukey test at 0.05 of significance. 
For the chlorophyll a content, the UFU-62-5M genotype grown under the single-row system differed only statistically from the UFU-28-1M genotype (Figure 3).

The simple-row system obtained a higher content of chlorophyll $a$, independently of the genotype, demonstrating greater gain in photosynthetic rate in relation to the double-row system, unlike the results obtained by Aminifard et al. (2012), who observed that, regardless of the density used in the cultivation of peppers, the chlorophyll content in the leaves did not differ.

All genotypes submitted to the double-row system presented similar chlorophyll content. This can be explained by the fact that smaller spacings between plants reduce the quality and amount of radiation that reaches the canopy in the lower stratum, thus interfering with chlorophyll content (Soares et al., 2009).

For the first germination count, all genotypes had similar behavior, except for UFU-28-1M, which had the highest number of germinated seeds when cultivated in a double-row (54\%) than when cultivated in single-row (15\%) (Figure 4), obtaining 3.6 times more seeds germinated when cultivated in double-row.

This difference in the percentage of germination for the genotype in question may have occurred due to the degree of maturity of the fruits. For fleshy fruit vegetables, such as pepper, the maturity of the seeds usually coincides with the beginning of the change of color of the fruits, usually of green for reddish spots

\section{Chlorophyll content $a$ and $b$}

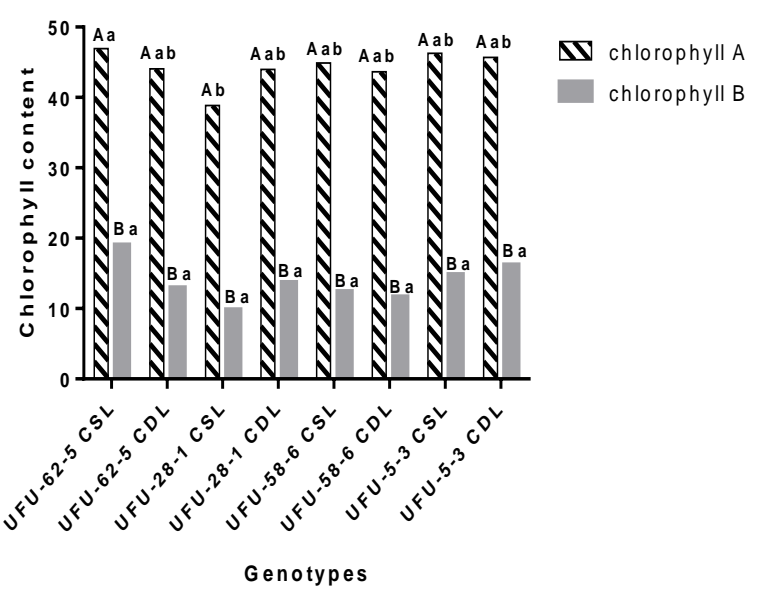

\footnotetext{
* Means followed by distinct letters, the uppercase between cultivation system and lowercase among genotypes, differ by Tukey test at 0.05 significance.

Figure 3. Chlorophyll $a$ and $b$ content of four pepper genotypes, grown at different planting systems. Federal University of Uberlândia, Monte Carmelo-MG, 2015.
}

(Pereira et al., 2014). Plants grown in larger spacings may have received higher solar radiation, and consequently, their fruits may have matured more quickly than more densely grown plants. Due to all the fruits, regardless of the cropping system, were harvested at the same time (100 days after transplantation), based on the visual appearance of the epicarp (changes in color and firmness). Also, the seed germination of the plants grown at lower spacings may possess a high degree of dormancy and, consequently, low germination (Queiroz et al., 2011).

Lal et al. (2016), studies the effects of the different planting densities in seed quality of bell pepper cv. Solan Bharpur under protected conditions, using three different planting densities $(45 \times 15 \mathrm{~cm}, 45 \times 30 \mathrm{~cm}$, and $45 \times 45 \mathrm{~cm})$. The maximum 1000-seed weight, germination percentage, seedling length, seedling dry weight, seedling vigor indexes were observed from spacing $45 \times 45$. Corroborating with this fact, Sajjan et al. (2004) in okra observed higher seedling length and dry weight with wider spaced plants.

Contrary to the results found in this work, Sanchez et al. (1993) reported 73-88\% germination in pepper influenced by plant spacing. Wide spaces with single stem plants conditioned with a favorable environment provided a better opportunity to increase the effectiveness of light and photosynthesis. Also, plants are less prone to competition for the resources that lead to healthy plants and larger fruits and ultimately result in healthier and more daring seeds of good quality.

First count of Germination (\%)

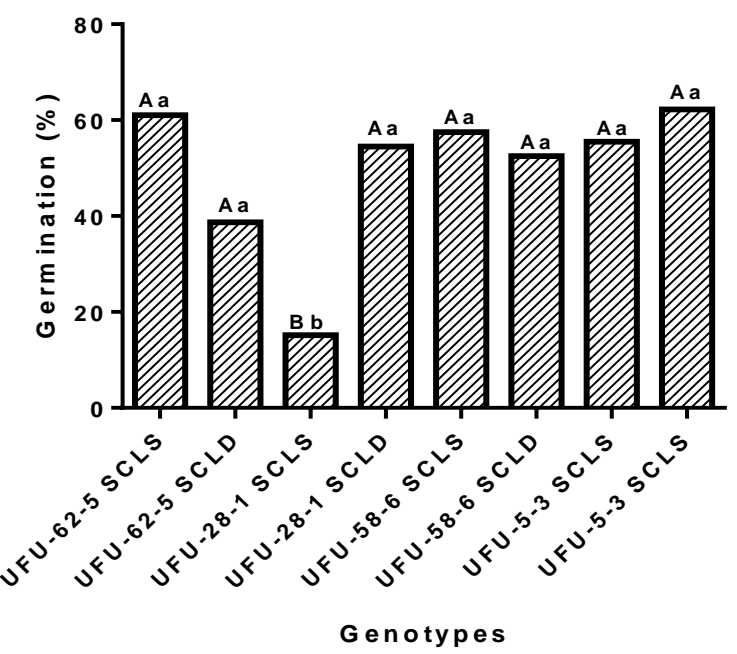

* Means followed by distinct letters, the uppercase between cultivation system and lowercase among genotypes, differ by Tukey test at 0.05 significance.

Figure 4. First germination count of four pepper genotypes, grown at different planting systems. Federal University of Uberlândia, Monte Carmelo-MG, 2015. 


\section{Conclusions}

Double-row planting presented significant increases in the physiological quality of pepper seeds of the genotype UFU-28-1M, not interfering in the agronomic performance in any evaluated genotype. Double-row planting system presented significant increases in the physiological quality of pepper seeds, thus for seed production, this would be the best system, because there are no differences in yield between the systems, the double-row system would be advantageous to facilitate the harvesting and allow future mechanization.

\section{Bibliographic References}

ABCSEM, 2009. Associação Brasileira do Comércio de Sementes e Mudas. Pesquisa de mercado de sementes de hortaliças.

http.//www.abcsem.com.br/docs/pesquisa_mercado_2009.pdf (acessado 18 de agosto de 2016).

Agrianual, 2012. Agrianual 2012: anuário da agricultura brasileira. São Paulo, FNP Consultoria e Comércio.

Al-Ramamneh, E.A.M., 2009. Plant growth strategies of Thymus vulgaris $\mathrm{L}$. in response to population density. Journal Industrial Crops and Products, 30(3), 389-394.

Aminifard, M.H., Aroiee, H., Ameri, A., Fatemi, H., 2012. Effect of plant density and nitrogen fertilizer on growth, yield and fruit quality of sweet pepper (Capsicum annuum). African Journal of Agricultural Research, 7(6), 859-866.

AOSA. Association of Official Seed Analysts, 1983. Seed vigor testing handbook. USA, East Lansing, p. 88.

Carvalho, S.I.C., Ribeiro, C.S.C., Henz, G.P., Reifschneider, F.J.B., 2009. 'BRS Mari': nova cultivar de pimenta dedo-demoça para processamento. Horticultura Brasileira, 27(4), 571573.

Domenico, C.I., Coutinho, J.P., Godoy, H.T., Melo, A.M.T., 2012. Caracterização agronômica e pungência em pimenta de cheiro. Horticultura Brasileira, 30(3), 466-472.

Dutra, F.L.A, Branco, I.G, Madrona, G.S., Haminiuk, C.W.I., 2010. Avaliação Sensorial e Influência do Tratamento Térmico no Teor de Ácido Ascórbico de Sorvete de Pimenta. Revista Brasileira de Tecnologia Agroindustrial, 4(2), 243251.

FAO, 2016. Food and Agriculture Organization of the United Nations. http://faostat.fao.org/site/339/default.aspx (accessed October 19, 2016)

Ferreira, D.F. 2011. Sisvar: A computer statistical analysis system. Ciência e Agrotecnologia, 35(6), 1039-1042.

Fonseca, R.M., Lopes, R., Barros, W.S., Lopes, M.T.G., Ferreira, F.M., 2008. Morphologic characterization and genetic diversity of Capsicum chinese Jacq. Accessions along the upper Rio Negro - Amazonas. Crop Breeding and Applied Biotechnology, 81(3), 187-197.

Goreta, S., Perica, S., Dumicić, G., Bućan, L., Zanić, K., 2005. Growth and yield of watermelon on polyethylene mulch with different spacings and nitrogen rates. HortScience, 40(2), 366369.

Khasmakhi-Sabet, A., Sedaghathoor, S.H., Mohammady, J., Olfati, A., 2009. Effect of plant density on Bell pepper yield and quality. International Journal of Vegetable Science, 15(3), 264-271.

Köppen, W., Geiger, R., 1928. Klimate der Erde. Gotha: Verlag Justus Perthes. Wall-map $150 \mathrm{~cm}$ x $200 \mathrm{~cm}$.

Lal, M., Kanwar, H.S., Kanwar, R., Lal, C., 2016. Effect of planting density and training on plant health and seed quality of Bell pepper (Capsicum апnиит L.) under protected conditions. Journal of Applied and Natural Science, 8(3), 1219-1222.

López-Bellido, F.J., López-Bellido, L., López-Bellido, R.J, 2005. Competition, growth and yield of faba bean (Vicia faba L.). European Journal of Agronomy, 23(4), 359-378.

Paulus, D., Valmorbida, R., Santin, A., Toffoli, E., Paulus, E., 2015. Crescimento, produção e qualidade de frutos de pimenta (Capsicum annuum) em diferentes espaçamentos. Horticultura Brasileira, 33(1), 91-100.

Pereira, F.E.C.B., Torres, S.B., Silva, M.I.L., Grangeiro, L.C., Benedito, C.P., 2014. Qualidade fisiológica de sementes de pimenta em função da idade e do tempo de repouso póscolheita dos frutos. Revista Ciência Agronômica, 45(4), 737 744.

Pôrto, D.R.Q., Cecilio Filho, A.B., Rezende, B.L.A., Barros Junior, A.P., Silva, G.S., 2012. Densidade populacional e época de plantio no crescimento e produtividade da couve-flor cv. Verona 284. Revista Caatinga, 25(2), 92-98.

Queiroz, L.A.F., Von Pinho, E.V.R., Oliveira, J.A., Ferreira, V.F., Carvalho, B.O., Bueno, A.C.R., 2011. Época de colheita e secagem na qualidade de sementes de pimenta Habanero Yellow. Revista Brasileira de Sementes, 33(3), 472-481.

Ribeiro, C.S.C., Reifschneider, F.J.B., 2008. Genética e melhoramento, in: Ribeiro, C.S.C., Lopes, C.A., Carvalho, S.I.C., Henz, G.P., Reifschneider, F.J.B., (Org.). Pimentas Capsicum. Brasília, Embrapa Hortaliças, p. 55-69.

Sajjan, A.S., Shekaragouwda, M., Biradar, B.D., 2004. Effect of sowing dates and spacing and nitrogen levels on seed yield and quality of okra (Abelmoschus esculentus L. Moench). Seed Research, 32(2), 118-121.

Sanchez, V.M., Sundstroml, F.J., Lang, N.S., 1993. Plant size influences bell pepper seed quality and yield. Horticulture Science, 28(8), 809-811.

Soares, A.B., Saror, L.R., Adami, P.F., Varella, A.C., Fonseca, L., Mezzalira, J.C., 2009. Influência da luminosidade no comportamento de onze espécies forrageiras perenes de verão. Revista Brasileira de Zootecnia, 38(3), 443-451.

Vidigal, D.S., Santos Dias, D.C.F., Santos Dias, L.A., Finger, F.L., 2011. Changes in seed quality during fruit maturation of sweet pepper. Scientia Agricola, 68(5), 535-539.

Vieira, R.D., Krzyzanowski, F.C., 1999. Teste de condutividade elétrica, in: Krzyzanowski, F.C., Vieira, R.D., França-Neto, J.B., (Ed.). Vigor de sementes: conceitos e testes. Londrina, Abrates, p. 1-20. 